\title{
Analisis Tingkat Pemahaman Konsep Fluida Statis dan Penerapannya di Lingkungan Sekitar pada Siswa SMA Negeri 2 Palu
}

\author{
Muhammad Shafar Husain, Yusuf Kendek, dan Fihrin \\ shafarayzha29@gmail.com \\ Program Studi Pendidikan Fisika FKIP Universitas Tadulako \\ Jl. Soekarno Hatta Km. 9 Kampus Bumi Tadulako Tondo Palu - Sulawesi Tengah
}

\begin{abstract}
Abstrak - Penelitian ini bertujuan untuk mengetahui tingkat persentase siswa yang dapat memahami materi fisika konsep fluida statis dan penerapannya dalam lingkungan sekitar, faktor yang mempengaruhi belajar siswa dan kemampuan menganalisis pristiwa sehari-hari berdasarkan pengetahuan fisika. Subjek penelitian adalah siswa kelas XI MIA SMA Negeri 2 Palu tahun ajaran 2016/2017. Responden penelitian diperoleh dengan teknik purposive sampling yaitu kelas yang memiliki hasil belajar tinggi yaitu siswa kelas XI MIA II sebanyak 24 siswa. Data diperoleh melalui tes pemahaman konsep beserta penerapannya dalam lingkungan sekitar, soal menganalisis, angket dan wawancara. Hasil dari penelitian ini menunjukkan bahwa pada tingkatan atau kategori I sebanyak $8 \%$, pada kategori II sebanyak $63 \%$ pada kategori III sebanyak $29 \%$. untuk faktor yang mempengaruhi hasil belajar mereka rata-rata faktor internal yaitu minat sebesar $78 \%$, dan motivasi sebesar $73 \%$, faktor eksternal yaitu keluarga sebesar $71 \%$, sarana dan prasarana sebesar $60 \%$ dan lingkungan masyarakat sebesar $67 \%$. Disamping itu kemampuan menganalisis siswa rata-rata diperoleh materi tekanan hidrostatis sebesar $29 \%$, hukum pascal $44 \%$, dan hukum archimedes sebesar $18 \%$. Sehingga dapat disimpulkan bahwa siswa yang memahami konsep fluida statis dan memahami penerapannya di lingkungan sekitar tergolong masih rendah, dan kemampuan mengerjakan soal analisis siswa juga tergolong masih rendah.
\end{abstract}

Kata Kunci: pemahaman konsep; penerapan lingkungan; fluida statis.

\section{PENDAHULUAN}

Fisika merupakan cabang ilmu pengetahuan yang mempelajari tentang materi dan segala aktifitas fisik dari materi yang menjadi dasar perkembangan ilmu pengetahuan dan teknologi. Fisika pada dasarnya bertujuan untuk mempelajari dan mengerti pemahaman kuantitatif teradap berbagai gejala atau proses alam dan sifat serta penerapannya. Disamping itu semua proses fisika dapat dipahami melalui sejumlah gejala alam yang bersifat dasar. Hukum alam itu sendiri dapat dipelejari dengan berbagai metode Pembelajaran, salah satunya.

Pemahaman terhadap konsep dapat menjadikan berbagai tuntutan pemikiran seperti mengingat, menjelaskan, menemukan fakta, menyebutkan contoh, menggeneralisasi, menerapkan, dan menganalogikan, dan menyatakan konsep baru dengan cara lain [1]. Selain itu, dalam penilaian aspek pengetahuan fisika mengacu pada pemahaman konsep yang berfungsi untuk menunjang pelaksanaan praktik [2].

Agar dapat melihat kemampuan memahami konsep terdapat 7 (tujuh) proses kognitif yang termasuk ke dalam kemampuan memahami (understand), yaitu: menafsirkan (interpreting), memberikan contoh (exemplinifying), mengklasifikasikan (classifying), meringkas (summarizing), menarik inferensi (inferring), membandingkan (comparing), dan menjelaskan (explaining) [3].
Pembelajaran berbasis lingkungan para siswa diajak memahami konsep sains untuk meningkatkan kecakapan berfikir mereka dengan menggunakan lingkungan sebagai sumber belajar. Seperti yang telah disebutkan diatas bahwa salah satu faktor yang mempengaruhi belajar siswa adalah faktor lingkungan [2]. Fisika dibutuhkan untuk mempelajari mempelajari fenomena alam yang menuntut kemampuan berfikir, Siswa diharapkan tidak hanya mempelajari tentang konsep, teori dan fakta ilmiah dalam diskusi di kelas tetapi juga dapat memahami aplikasi konsep fisika tersebut dalam kehidupan sehari-hari [4].

Proses pembelajaran IPA atau fisika menekankan pada pemberian pengalaman langsung untuk mengembangkan kompetensi agar peserta didik menjelajahi dan memahami alam secara ilmiah. Fenomena alam yang terjadi dapat membantu siswa dalam membangun konsep dan nilai [5]. Dalam mempelajari gelaja atau fenomena alam, fisika menggunakan proses yang terdiri atas; pengamatan, pengukuran, analisis, dan penarikan kesimpulan. Untuk memperoleh hasil belajar yang baik dalam fisika, siswa seharusnya dapat mengembangkan kemampuan berpikirnya dan tidak hanya sekedar menghafal pelajaran, tetapi dalam pembelajaran siswa mampu memahami konsep-konsep yang diajarkan sehingga siswa dapat memecahkan dan mencari solusi dari suatu persoalan [6].

Kenyataannya proses pembelajaran konsep fluida statis di sekolah masih didominasi oleh metode pembelajaran yang cenderung bersifat 
informatif dan lebih ditekankan pada perumusan persamaan matematis sehingga kurang memberikan pengalaman nyata pada siswa dalam berinteraksi langsung dengan fenomena fluida statis yang dipelajari. Fluida statis merupakan konsep yang dapat diaplikasikan dan sering ditemui siswa dalam kehidupan seharihari. Karakter konsep seperti ini sudah seharusnya dibelajarkan dengan memberikan pengalaman nyata kepada siswa. Pemberian pengalaman nyata dalam memecahkan masalah terkait fluida statis dalam kehidupan sehari-hari diharapkan mampu menanamkan pada siswa kemampuan memahami secara utuh dan lebih mendalam, serta membekali siswa kemampuan untuk mengaplikasikan konsep yang dimilikinya dalam memecahkan masalah.

Pendekatan pembelaran tradisional yang berfokus pada guru suda tidak cocok lagi digunakan dalam pembelajaran yang mengutamakan penanaman konsep, sehingga siswa diharapkan dapat menarik sendiri konsep fisika melalu percobaan maupun pengamatan langsung gejala alam sekitar. Fisika dibutuhkan untuk mempelajari fenomena alam yang menuntut kemampuan berpikir sehingga percobaan fisika di sekolah penting dilakukan oleh siswa untuk dapat memahami prinsip dan konsep fisika. Siswa diharapkan tidak hanya mempelajari tentang konsep, teori, dan fakta ilmiah dalam diskusi di kelas tetapi juga dapat memahami aplikasi konsep fisika tersebut dalam kehidupan sehari-hari. Dalam kenyataannya banyak siswa yang mampu menguasai materi fisika namun mereka belum bisa memahami aplikasinya dalam kehidupan sehari-hari

\section{METODE PENELITIAN}

Penelitian ini dimaksudkan untuk mengetahui berapa persentase tingkat pemahaman siswa yang memahami konsep fisika juga memahami penerapan di lingkungan sekitar, faktor-faktor yang mempengaruhi pemahaman konsep siswa juga untuk mengetahui kemampuan siswa dalam menganalisis peristiwa sehari-hari berdasar materi fisika. Jenis penelitian dalam penelitian ini adalah penelitian deskriptif kualitatif. Dengan penelitian deskriptif kualitatif penulis menggambarkan atau menjelaskan variable yang telah diteliti melalui data-data yang diambil dari penelitian, kemudian dianallisis dan diambil suatu kesimpulan sabagai hasil penelitian. Dalam hal ini penelitian hanya menganalisis pemahaman konsep fluida statis dan penerapannya dalam lingkngan sekitar pada siswa SMA disalah satu SMA Negeri di kota Palu.

Penelitian ini akan dilaksanakan pada salah satu SMA Negeri di Kota Palu yaitu SMA Negeri 2
Palu. Penelitian ini dilaksanakan pada bulan Maret-April 2017. Subjek dalam penelitian ini adalah kelas XI MIA SMA Negeri 2 Palu tahun ajaran 2016/2017. Penulis menentukan responden dengan teknik purposive sampling yaitu pemilihan responden berdasarkan pertimbangan tertentu dari guru fisika bersangkutan diantaranya yaitu kelas yang memiliki nilai rata-rata hasil belajar Fisika yang tinggi. Responden yang diambil dalam penelitian ini adalah kelas XI MIA yang berjumlah 6 orang yang diambil menggunakan teknik purposive sampling untuk mengikuti wawancara secara mendalam. Teknik pengambilan responden pada penelitian ini yaitu berdasarkan kategori nilai tinggi, sedang dan rendah.

Data diperoleh dengan memberikan tes pemahaman konsep Untuk mengetahui berapa persentase siswa yang memahami materi fisika juga memahami penerapan konsep di lingkungan sekitar dan faktor-faktor yang mempengaruhinya, maka penulis melakukan penelitian dengan pengumpulan data dalam bentuk tes, angket dan wawancara.

Pedoman penskoran dan kriteria penilaian yang digunakan untuk mengukur kemampuan pemahaman konsep siswa dan kemampuan menganalisis peristiwa dalam penerapannya dilingkungan sekitar berdasarkan materi dan indikatornya pada penelitian ini adalah sebaga berikut [7] :

$$
N=\frac{\sum \text { skor perolehan }}{\sum \text { skor maksima }} \times 100 \%
$$

Menentukan kriteria dari rata-rata persentase [8].

\begin{tabular}{cc}
\multicolumn{2}{c}{ TABEL KUALIFIKASI HASIL TES } \\
\hline Rentang Skor $(\%)$ & Kriteria \\
\hline $66,68 \leq \mathrm{Z} \leq 100$ & Tinggi \\
$33,34 \leq \mathrm{Z} \leq 66,67$ & Sedang \\
$0 \leq \mathrm{Z} \leq 33,33$ & Rendah \\
\hline
\end{tabular}

Hasil persentase skor pemahaman konsep dan penerapan di lingkungan sekitar maka diperoleh kategori-kategori siswa dengan ketentuan sebagai berikut [1]:

a. Kategori I (Tinggi) yaitu siswa dapat memahami konsep fisika juga dapat memahami perapannya di lingkungan sekitar.

b. Kategori II (Sedang) yaitu siswa dapat memahami konsep fisika tetapi tidak paham penerapannya di lingkungan sekitar.

c. Kategori III (Rendah) yaitu siswa tidak memahami konsep fisika tetapi terampil dalam penerapannya di lingkungan sekitar.

Data yang diperoleh dari pertanyaan yang terdapat di lembar angket berupa data kualitatif, agar data tersebut dapat diukur, maka diadakan transformasi dari data kualitatif menjadi data 
p-ISSN 2338-3240, e-ISSN 2580-5924

kuantitatf dengan cara memberi skor pada setiap jawaban soal tersebut. Penilaian angket yang digunakan adalah berdasarkan skala likert, dengan ketentuan sebagai berikut:

Untuk pernyataan Positif

a. Alternatif jawaban sangat setuju diberi skor 4

b. Alternatif jawaban setuju diberi skor 3

c. Alternatif jawaban tidak setuju diberi skor 2

d. Alternatif jawaban sangat tidak setuju diberi skor 1

Untuk pernyataan Negatif

a. Alternatif jawaban sangat setuju diberi skor 1

b. Alternatif jawaban setuju diberi skor 2

c. Alternatif jawaban tidak setuju diberi skor 3

d. Alternatif jawaban sangat tidak setuju diberi skor 4

Berdasarkan pedoman penskoran yang telah dibuat, maka dalam menghitung persentase skor hasil angket digunakan cara sebagai berikut:

$$
\bar{x}=\frac{a}{b} \times 100 \%
$$

Keterangan:

$\mathrm{x}^{-}$: persentase skor angket penelitian.

$a$ : jumlah skor yang diperoleh

$b$ : jumlah skor maksimal

Menghitung rata-rata persentase skor observasi tiap-tiap pembelajaran lalu dikategorikan sesuai dengan kualifikasi hasil persentase observasi [8].

TABEL KUALIFIKASI HASIL PERSENTASI SKOR ANGKET

\begin{tabular}{cc}
\hline Rentang Skor $(\%)$ & Kriteria \\
\hline $66,68 \leq \bar{x} \leq 100$ & Tinggi \\
$33,34 \leq \bar{x} \leq 66,67$ & Sedang \\
$0 \leq \bar{x} \leq 33,33$ & Rendah
\end{tabular}

Dilakukan juga wawancara kepada subjek penelitian untuk memperoleh data tentang faktor-faktor yang mempengaruhi siswa dalam memahami konsep. Sehingga diperoleh kesimpulan dari angket, wawancara subjek dan wawancara guru untuk memperoleh data faktorfaktor yang mempengaruhi pemahaman konsep siswa.

\section{HASIL DAN PEMBAHASAN}

\section{A. Hasil Penelitian}

Data yang diperoleh selama penelitian berupa hasil tes tertulis yang berisi soal pemahaman konsep, soal penerapan di lingkungan sekitar, dan soal analisis, angket dan wawancara untuk mengetahui faktor-faktor yang mempengaruhi pemahaman belajar siswa.data-data yang diperoleh kemudian dianalisa untuk menunjukkan tingkat pemahaman siswa dari tes objektif dan faktor-faktor yang mempengaruhi pemahaman siswa melalui angket dan wawancara.
Tingkat pemahaman konsep siswa dan penerapannya di lingkungan dapat dilihat dari hasil jawaban peserta tes yang berupa soal pemahaman konsep dan soal penerapan lingkungan.

\begin{tabular}{cccc}
\multicolumn{4}{c}{ TABEL DISTRIBUSI PEMAHAMAN KONSEP DAN PENERAPANNYA } \\
DILINGKUNGAN SEKITAR
\end{tabular}

Analisis pemahaman konsep fluida statis dan penerapannya dilingkungan sekitar berdasarkan indikator dan kemampuan menganalisis peristiwa seperti yang diperlihatkan pada tabel 4.

\begin{tabular}{cccccccc}
\multicolumn{7}{c}{ TABEL ANALISIS PEMAHAMAN KONSEP FLUIDA STATIS DAN PENERAPANNYA } \\
DALAM LINGKUNGAN SEKITAR MENURUT INDIKATOR \\
\hline \multirow{2}{*}{ Kategori } \\
\cline { 2 - 8 } & 1 & 2 & 3 & 4 & 5 & 6 & 7 \\
\hline I & 34 & 83 & 83 & 75 & 100 & 83 & 50 \\
II & 64 & 62 & 53 & 53 & 80 & 57 & 28 \\
III & 33 & 67 & 29 & 33 & 57 & 52 & 19 \\
\hline
\end{tabular}

Keterangan:

$$
\begin{aligned}
& 1 \text { : Interpretasi } \\
& 2 \text { : Mencontohkan } \\
& 3 \text { : Mengklasifikasikan } \\
& 4 \text { : Menggeneralisasikan } \\
& 5 \text { : Menginferensi } \\
& 6 \text { : Membandingkan } \\
& 7 \text { : Menjelaskan }
\end{aligned}
$$

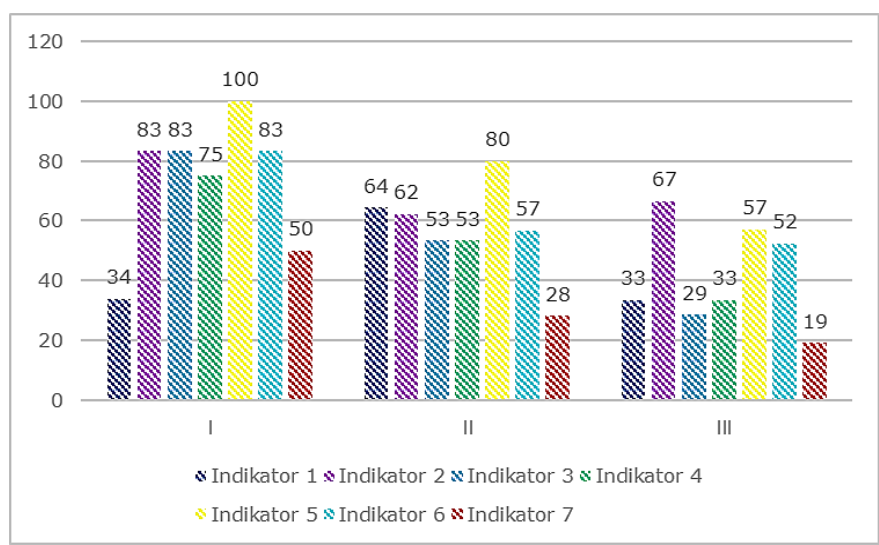

Gbr. Analisis Pemahaman Konsep Fluida Statis dan Penerapannya dalam Lingkungan Sekitar Menurut Indikator 
TABEL KEMAMPUAN MENGANALISIS PERISTIWA SEHARI-HARI BERDASARKAN

\begin{tabular}{cccc} 
& \multicolumn{3}{c}{ PENGETAHUAN FISIKA } \\
\hline \multirow{2}{*}{ Kategori } & \multicolumn{3}{c}{ Menganalisis (\%) } \\
\cline { 2 - 4 } & $\begin{array}{c}\text { Tekanan } \\
\text { Hidrostatis }\end{array}$ & $\begin{array}{c}\text { Hukum } \\
\text { Pascal }\end{array}$ & $\begin{array}{c}\text { Hukum } \\
\text { Archimedes }\end{array}$ \\
\hline I & 80 & 70 & 50 \\
II & 36 & 61 & 21 \\
III & 0 & 0 & 0 \\
\hline
\end{tabular}

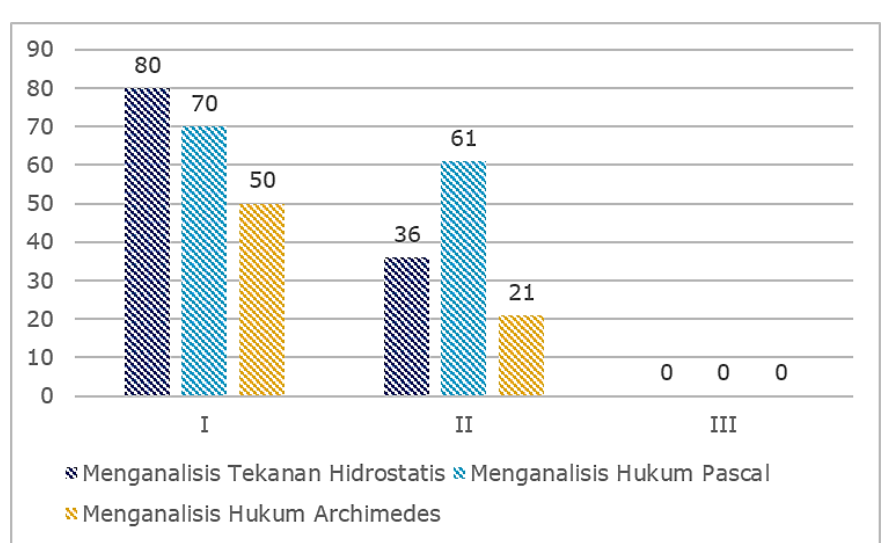

Gbr. Kemampuan Menganalisis Peristiwa Sehari-hari Berdasarkan Pengetahuan Fisika

Selain hasil penemuan di atas, diperoleh memperoleh data sebagai hasil dari penyebaran angket kepada siswa-siswi tersebut. Angket beirisi faktor-faktor yang mempengaruhi belajar siswa yang dilihat dari empat indikator yaitu diri sendiri, sarana prasarana, lingkungan keluarga dan lingkungan masyarakat.

TABEL HASIL PERHITUNGAN ANGKET

\begin{tabular}{|c|c|c|c|c|c|}
\hline \multirow{2}{*}{ No } & \multirow{2}{*}{ Faktor-faktor } & \multicolumn{3}{|c|}{ Kategori (\%) } & \multirow{2}{*}{$\begin{array}{l}\text { Rata- } \\
\text { rata (\%) }\end{array}$} \\
\hline & & I & II & III & \\
\hline 1 & Motivasi & 73 & 78 & 68 & 73 \\
\hline 2 & Minat & 77 & 83 & 73 & 78 \\
\hline 3 & Keluarga & 63 & 80 & 70 & 71 \\
\hline 4 & $\begin{array}{l}\text { Sarana Dan } \\
\text { Prasarana }\end{array}$ & 46 & 73 & 60 & 60 \\
\hline 5 & $\begin{array}{l}\text { Lingkungan } \\
\text { Masyarakat }\end{array}$ & 73 & 68 & 60 & 67 \\
\hline
\end{tabular}

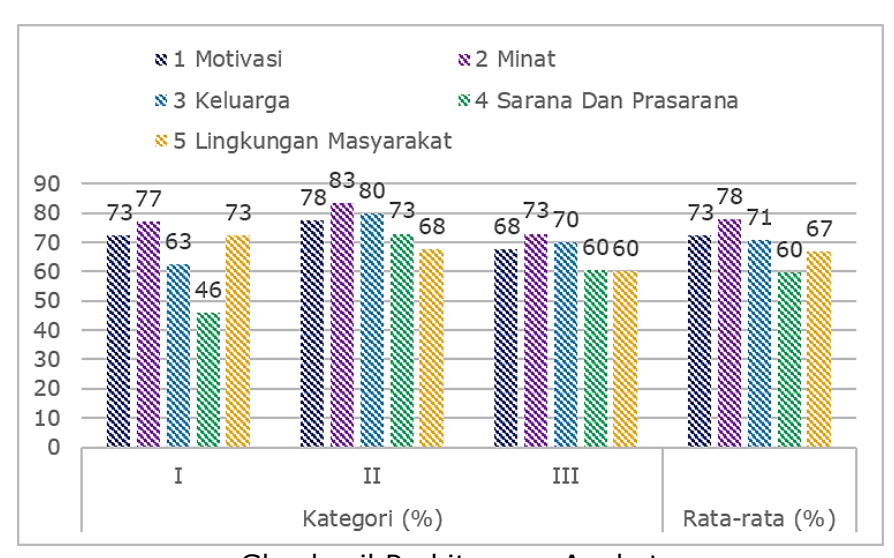

Gbr. hasil Perhitungan Angket

Wawancara digunakan sebagai salah satu metode dalam pengumpulan data. Untuk menghasilkan data yang akurat, maka peneliti melakukan wawancara kepada 6 subjek penelitian yang diambil dari masing-masing kategori dan guru fisika. Wawancara digunakan untuk memperoleh data faktor-faktor yang mempengaruhi belajar siswa.

Berdasarkan hasil petikan wawancara untuk pertanyaan pertama pada Siswa kategori I dapat disimpulkan bahwa pembelajaran fisika lumayan disenangi siswa. Pada siswa kategori II dapat disimpulkan bahwa pelajaran fisika sangat disenangi. Pada siswa kategori III dapat disimpulkan bahwa pelajaran fisika tidak terlalu disenangi siswa.

Pertanyaan kedua pada siswa kategori I dapat disimpulkan bahwa siswa sudah berada dalam kelas sebelum pembelajaran dimulai. Pada siswa kategori II dapat disimpulkan bahwa siswa sudah datang diluan sebelum pembelajaran dimulai. Sedankan pada siswa kategori III dapat disimpulkan bahwa sebelum pembelajaran dimulai siswa sudah datang terlebih dahulu.

Untuk pertanyaan ketiga pada siswa kategori I dapat disimpulkan bahwa siswa sering mengerjakan tugas sendiri, namun jika ada kesulitan baru ditanyakan kepada teman. Pada siswa kategori II dapat disimpulkan bahwa siswa selalu mengerjakan tugas sendiri, dan kalau ada masalah ditanyakan keguru. Pada siswa kategori III dapat disimpulkan bahwa siswa merasa kesulitan kalau ada tugas, tapi lebih cenderung untuk kerja sama dengan teman untuk menyalesaikan tugas.

Dari pertanyaan keempat pada siswa kategori I dapat disimpulkan bahwa jam siswa dalam belajar masih kurang. Pada Siswa kategori II dapat disimpulkan bahwa siswa tidak belajar diwaktu lain hanya belajar saat jam pelajaran saja. Pada Siswa kategori III dapat disimpulkan bahwa siswa juga masih memiliki waktu belajar yang kurang.

Pada pertanyaan kelima siswa kategori I dapat disimpulkan bahwa siswa lebih mudah memahami materi fluida statis. Pada siswa kategori II dapat disimpulkan bahwa siswa menganggap materi fluida statis lebih mudah dipahami dari ang lain. Pada siswa kategori III dapat disimpulkan bahwa siswa menganggap materi fluida statis agak lemaan dapat dimengerti.

Selain itu pada pertanyaan keenam siswa kategori I dapat disimpulkan bahwa guru sangat baik dalam menjelaskan dan siswa dapat menagkap dan memahami materi yang diajarkan. Pada siswa kategori II dapat disimpulkan bahwa guru sangat bagus dalam menjelaskan dan siswa dapat menagkap dan memahami materi yang diajarkan oleh guru. Pada siswa kategori III dapat disimpulkan bahwa 
guru baik dalam menjelaskan tapi kadang materinya ad yang dapat dimengerti dan ad juga yang tidak dimengerti.

Pertanyaan ketujuh pada siswa kategori I dapat disimpulkan bahwa siswa kadang mendapatkan kesulitan biasana dari bentuk soal yang kadang membingungkan. Pada siswa kategori II dapat disimpulkan bahwa siswa kadang mendapatkan kesulitan biasana dari penggunaan rumus yang sesuai yang dapat digunakan dan rumusnya juga terlalu banyak sehingga membingungkan. Pada siswa kategori III dapat disimpulkan bahwa siswa kadang mendapatkan kesulitan biasana dari rumus yang kurang dimengerti dan rumusnya yang cocok untuk soal tersebut.

Dilihat dari pertanyaan kedelapan pada siswa kategori I dapat disimpulkan bahwa siswa mempunyai buku cetak fisika sendiri. Pada kategori II dapat disimpulkan bahwa siswa mempunyai pegangan buku fisika. Pada kategori III dapat disimpulkan bahwa siswa mempunyai buku cetak.

Dari pertanyaan kesembilan pada siswa kategori I dapat disimpulkan bahwa sarana dan prasarana disekolah masi sangat minim, Lab. Fisika yang tak pernah difungsikan dan buku yang kurang diperpustakaan. Pada siswa kategori II dapat disimpulkan bahwa sarana dan prasarana disekolah masi sangat kurang, Lab. Fisika yang tak pernah difungsikan, alatnya tidak banyak, dan kurangnya buku yang disedikan. Pada siswa kategori III dapat disimpulkan sarana dan prasarana disekolah masi kurang lengkap, serta Lab. Fisika yang tidak digunakan.

Untuk pertanyaan kesepuluh pada siswa kategori I dapat disimpulkan bahwa keadaan lingkungan dirumah mendukung dalam hal belajar fisika mereka. Pada siswa kategori II dapat disimpulkan bahwa keadaan lingkungan mereka sedikit mendukung karena ad buku fisika tetapi ada juga yang tidak mendukung sehingga dia sulit untuk mendapatkan literature dalam belajar. Pada siswa kategori III dapat disimpulkan bahwa keadaan lingkungan mereka cukup mendukung di karenakan ada internet dan ada juga buku.

Pada pertanyaan kesebelas siswa kategori I dapat disimpulkan bahwa perhatian dari orang tua terhadap belajar siswa tidak ada. Pada siswa kategori II dapat disimpulkan bahwa perhatian orang tua terhadap belajar siswa masi kurang. Pada siswa kategori III dapat disimpulkan bahwa siswa masi diperhatikan belajarnya oleh oaring tua mereka.

Hasil dari pertanyaan keduabelas pada siswa kategori I disimpulkan bahwa siswa bingung dalam mengerjakan soal, dan penggunaan rumus yang tepat untuk soal. Pada siswa kategori I dapat disimpulkan bahwa siswa dalam mengerjakan soal tidak menemukan kesulitan cuman biasa-biasa saja, kadang bingung saat penggunaan rumus. Pada siswa kategori III dapat disimpulkan bahwa siswa menemukan maslah saat menyelesaikan soal cerita.

Berdasarkan pertanyaan ketigabelas pada siswa kategori I dapat disimpulkan bahwa materi fluida statis tidak terlalalu menyulitakan meraka. Pada siswa kategori II dapat disimpulkan bahwa siswa merasa materi ini tidak terlalu menyulitkan mereka. Pada Siswa kategori III dapat disimpulkan materi fluida statis tidak terlalu susah jika dibandingkan dengan yang lain.

Hasil wawancara yang dilakukan dengan Ibu Wanda, selaku Guru Fisika kelas XI MIA II diperoleh beberapa hasil yaitu :

a. Materi Fluida Statis agak mudah dipahami siswa dibandingkan dengan materi yang lain.

b. Siswa-siswi antusias dan aktif mengikuti pembelajaran fisika khususnya pada materi Fluida Statis.

c. Guru sering memberikan tugas dikelas untuk dikerjakan oleh siswa

d. Siswa lebih tertarik dengan fisika ketika guru menjelaskannya dengan mudah dan disertai contoh penerapannya dalam kehidupan sehari-hari.

e. Metode pembelajaran yang dilakukan oleh guru dengan ceramah dan demonstrasi.

f. Kendala-kendala yang dihadapi saat mengajarkan Fisika khususnya materi Fluida Statis yaitu tidak terdapat ruang laboratorium serta alat yang memungkinkan dan efisien yang dapat digunakan untuk praktikum, sehingga guru hanya menggunakan demonstrasi di kelas.

\section{B. Pembahasan}

Siswa kategori I, menunjukkan bahwa siswa telah berada pada tingkatan pemahaman relasional (relational understanding), dimana menurut Skemp siswa tidak hanya sekedar tahu dan hafal tentang suatu hal namun juga tahu mengapa itu terjadi dan dapat menggunakannya untuk menyelesaikan masalah-masalah yang terkait pada situasi lain. Hal ini berarti bahwa disamping siswa memahami konsep fisika dengan baik, siswa juga memahami penerapannya di lingkungan sekitar.

Kategori selanjutnya yaitu pada siswa kategori II, menunjukkan bahwa siswa berada pada tingkatan pemahaman instruksional (instructional understanding), dimana menurut Skemp siswa baru berada di tahap tahu atau hafal tetapi belum atau tidak tahu megapa hal itu dapat terjadi dan juga belum atau tidak bisa menerapkan hal tersebut pada keadaan baru yang berkaitan. Hal ini berarti siswa memahami 
konsep fisika tapi tidak memahami penerapnnya di lingkunga sekitar.

Pada tingkatan pemahaman intuitif (intuitive understanding) yaitu pada siswa kategori III, menunjukkan bahwa dimana pada tahap ini siswa sering menebak jawaban berdasarkan pengalaman-pengalaman keseharian dan tanpa melakukan analisis terlebih dahulu. Akibatnya meskipun siswa dapat menjawab suatu pertanyaan yang benar, tetapi tidak dapat menjelaskan kenapa (why). Hal ini berarti siswa tidak memahami konsep fisika dengan baik namun dapat mengetahui penerapannya di lingkungan sekitar.

Berdasarkan analisis soal yang diberikan pada siswa yang mengandung materi fluida statis, mencakup Tekanan Hidrostatika, Hukum Paskal, dan Hukum Archimedes.

Peneliti menganalisis kemampuan pemahaman konsep siswa dan kemampuan penerapan fisika di lingkungan sekitar dengan menggunakan materi fluida statis dengan berdasarkan indikator yang ada. Berdasarkan analisis soal yang diberikan pada siswa yang mengandung materi fluida statis, mencakup Tekanan Hidrostatika, Hukum Paskal, dan Hukum Archimedes. Jumlah soal yang digunakan pada penelitian ini adalah 14 butir soal esai yang terdiri dari 5 nomor soal tentang pemahaman konsep, 6 nomor soal berdasarkan penerapannya dilingkungan dan 3 nomor soal menganalisis peristiwa. Berdasarkan hasil analisis data yang dilakukan, diperoleh bayaknya siswa yang masuk Kategori I sebanyak 2 orang atau sebesar $8,33 \%$, Kategori II sebanyak 15 orang atau sebesar 62,50\%, dan Kategori III sebanyak 7 orang atau sebesar 29,17\%. Hal ini menunjukkan bahwa siswa yang memahami konsep fisika juga memahami penerapannya di lingkungan sekitar masih tergolong rendah.

Pada analisis soal untuk mengukur pemahaman konsep yang diberikan pada siswa dimana soal nomor 1 pada konsep tekanan hidrostatis pada aspek atau indikator menginterpretasi. Pada soal nomor 2 masih sama yaitu pada konsep tekanan hidrostatis tetapi pada indikator mengklasifikasikan. Pada soal nomor 3 yaitu pada konsep hukum Pascal pada indikator menggeneralisasikan. Pada soal nomor 4 yaitu pada konsep hukum Archimedes tetapi pada indikator membandingkan. Dan pada soal nomor 5 yaitu pada konsep hukum Archimedes pada indikator menjelaskan.

Analisis soal untuk mengukur kemampuan memahami penerapannya fluida statis dilingkungan sekitar pada soal nomor 6 yaitu pada konsep tekanan hidrostatis dengan aspek atau indikator mencontohkan. Soal nomor 7 masi sama pada konsep tekanan hidrostatis tetapi pada indikator membandingkan. Pada soal nomor 8 masi pada konsep tekanan hidrostatis tetapi pada indikator menginferensi. Pada soal nomor 9 konsep hukum Pascal dengan indikator menjelaskan. Pada soal nomor 10 pada konsep hukum Archimedes dengan indikator menjelaskan. Soal nomor 11 masi pada konsep yang sama yaitu hukum Archimedes tetapi pada indikator berbeda yaitu menggeneralisasikan.

Untuk mengetahui kemampuan menganalisis peristiwa sehari-hari diberikan 3 butir soal pada soal nomor 12 pada konsep tekanan hidrostatis. Pada soal nomor 13 yaitu pada konsep atau materi hukum Pascal. Pada soal nomor 14 yaitu pada materi pada materi hukum Archimedes.

Peneliti menganalisis kemampuan pemahaman konsep siswa dan penerapan fisika di lingkungan sekitar dengan didasarkan indikator pemahaman. Dari hasil analisis, diperoleh bahwa untuk indikator 1 menginterpretasi yang terdapat pada soal nomor 1 yang berbunyi manakah tekanan yang lebih besar, tekanan didasar sebuah tabung yang dalamnya $1,8 \mathrm{~m}$, atau tekanan didasar sebuah danau yang dalamnya $1 \mathrm{~m}$. pada kategori I berdasarkan hasil pengerjaan soal diperoleh kemampuan pemahaman konsep dan menganalisis peristiwa dalam kehidupan seharihari sebesar $34 \%$, pada kategori II sebesar $64 \%$ dan pada kategori III sebesar $33 \%$. Ini berarti bahwa kategori I dan III sangat lemah dalam hal interpretasi yaitu mengubah dari bentuk yang satu kebentuk yang lain.

Untuk indikator mencontohkan yaitu pada Indikator 2 terdapat pada soal nomor 6 yang berbunyi mengapa mulut teko dibuat lebih tinggi dari pada badan teko. diperoleh pada kategori I kemampuan pemahaman konsep dan menganalisis peristiwa sebesar $83 \%$, pada kategori II sebesar $62 \%$ dan pada kategori III sebesar $67 \%$. Ini berarti bahwa baik kategori I, II, maupun III sedikit mampu mengerjakan soal dalam hal menemukan contoh khusus menggambarkan dari suatu konsep atau prinsip.

Dalam hal mengklasifikasikan yaitu pada Iindikator 3 terdapat pada soal nomor 2 yang berbunyi terdapat beberapa besaran yaitu massa jenis, diameter benda, percepatan gravitasi, kedalaman zat cair, dan bentuk atau ukuran wadah. Manakah besaran yang mempengaruhi tekanan zat cair. Diperoleh kemampaun pemahaman konsep dan menganalisis peristiwa pada kategori I yaitu sebesar $83 \%$, kategori II sebesar $53 \%$, dan kategori III sebesar $29 \%$. Ini menunjukkan bahwa kategori III sangat lemah dalam hal menentukan sesuatu yang dimiliki oleh suatu kategori

Dari segi menggeneralisasikan atau pada Indikator 4 yaitu terdapat pada soal nomor 3 yang berbunyi sebuah percobaan yaitu dengan 
kantong pelastik yang dibagian sisinya diberi beberapa lubang, diisi, air lalu ditekan. Merupakan contoh dari percobaan untuk membuktukan hukum apa coba kamu jelaskan. dan soal nomor 11 yang berbunyi mengapa anda lebih mudah mengapung dipermukaan air laut dari pada dipermukaan air sungai. Hasil analisis menunjukan kemampuan pemahaman konsep dan menganalisis peristiwa siswa pada kategori I yaitu sebesar $75 \%$, kategori II sebesar $53 \%$, dan kategori III sebesar 33\%. Ini menunjukkan bahwa kategori III sangat lemah dalam hal menggeneralisasikan atau megabstrakkan tematema umum atau poin-poin utama.

Indikator 5 menginferensi yaitu terdapat pada soal nomor 8 yang berbunyi yaitu saat kita menyelam didalam air, maka telinga kita akan terasa sakit dan kitika akan menyelam semakin dalam maka akan terasa semakin sakit, mengapa demikian. diamana untuk kategori I menunjukkan kemampuan pemahaman konsep dan penerapannya sebesar $100 \%$, kategori II sebesar $80 \%$ dan kategori III sebesar $57 \%$. Ini menenjukkan bahwa baik siswa kategori I, II, dan III mampu dalam hal menginferensi atau menggambarkan kesimpulan logis dari informasi yang disajikan.

Untuk segi membandingkan atau pada Indikator 6 yaitu terdapat pada soal nomor 4 yang berbunyi jika masa benda lebih kecil dari pada massa jenis air, maka apa yang terjadi dengan benda tersebut dan soal nomor 7 yang berbunyi mengapa saat kita berdiri dengan 1 kaki akan terasa lebih sulit dari pada berdiri dengan dua kaki. Menunjukan kemampuan pemahaman konsep dan penerapannya dilingkungan sekitar diperoleh untuk kategori I sebesar $83 \%$, kategori II sebesar $57 \%$ dan kategori III sebesar 52\%. Ini menunjukkan bahwa baik kategori I, II, maupun III dapat mengerjakan soal dalam hal mencari hubungan antara dua ide, objek atau hal-hal serupa.

Indikator 7 yaitu menjelaskan terdapat pada soal 5 yaitu berbunyi neraca pegas saat mengangkat beban diudara skalanya T1 saat didalam air skalanya T2 ternyata T1 > T2 Mengapa demikian. Soal nomor 9 berbunyi saat montir akan memasang ban mobil yaitu dengan menggunakan dongkrak hidrolik, dapatkah kamu menjelaskan bagaimana prinsip kerjanya dan cara menggunakan dongkrak hidrolik. Dan soal nomor 10 berbunyi mengapa kapal yang terbuat dari besi dapat terapung diatas air. Menunjukkan kemampuan pemahaman konsep dan penerapannya pada kategori I diperoleh sebesar $50 \%$, kategori II sebesar $28 \%$, dan kategori III sebesar 19\%. Ini menunjukan bahwa baik itu kategori I, II, maupun kategori III sangat lemah dalam pengerjaan soal yang mengkonstruksika model sebab akibat dari suatu system.

Dilihat dari segi indikator bahwa siswa kategori I, II dan III mampu mengerjakan soal dengan model berdasarkan indikator 5 yaitu menginferensikan soal pemahaman konsep fisika dan penerapan dilingkungan sekitar dengan baik, siswa cenderung menyukasi soal-soal yang menuntut kemampuan menginferensikan yaitu menggambarkan kesimpulan logis dari informasi yang disajikan, dibandingkan dengan yang lainnnya. Namun siswa sangat lemah pada indikator 1 dan 7 yaitu menginterprestasi dan menjelaskan Sehingga dapat diketahui bahawa siswa sangat lemah dalam hal mengubah suatu bentuk dan menjelaskannya, hal ini sesuai dengan riset yang dilakukan oleh Programme of International Students Assesment pada acara Science Competencies for Tommorow's World bulan Desember 2007 [9], menyatakan bahwa siswa Indonesia belum ada sama sekali yang mampu mengidentifikasi, menjelaskan serta megaplikasikan pengetahuan dan sains dalam berbagai situasi kehidupa yang kompleks secara kosisten.

Siswa lebih cenderung mempunyai pengetahuan sains yang terbatas. [10] menyarankan agar pertanyaan-pertanyaan pada soal bersifat analitis yang tidak hanya mengandalkan hafalan. Sehingga diharapkan siswa tidak hanya mengandalkan rumus. Dalam hal ini, peneliti juga ingin menganalisis kemampuan siswa dalam mengenalisis peristiwa dalam kehidupa sehari-hari berdasarkan fisika.

Kemampuan siswa dalam mengenalisis peristiwa dalam kehidupan sehari-hari berdasarkan pengetahuan fisika. Untuk kategori I di peroleh hasil untuk materi Tekanan Hidrostatis sebanyak $80 \%$, untuk materi hukum Pascal sebanyak $70 \%$, sedangkan untuk materi hukum Archimedes sebanyak 50\%. Dapat dikatakan bahwa pada kategori I untuk kemampuan menganalisis peristiwa di lingkungan sekitar berdasarkan pengetahuan fisika menunjukkan bahwa kemampuan analisis siswa sudah cukup tinggi, dimana soal analisis berisi soal-soal yang menuntut siswa berfikir secara matematis.

Kategori II kemampuan menganalisis peristiwa dalam kehidupan sehari-hari sudah jauh lebih rendah dari pada kategori I dimana hanya ada beberapa siswa yang mampu menjawab beberapa soal dengan baik, di peroleh hasil untuk materi Tekanan Hidrostatis sebanyak 36\%, untuk materi hukum Pascal sebanyak 61\%, sedangkan untuk materi hukum Archimedes sebanyak $21 \%$. Dapat dikatakan bahwa pada kategori II untuk kemampuan menganalisis peristiwa di lingkungan sekitar berdasarkan 
pengetahuan fisika menunjukkan bahwa kemampuan analisis siswa cukup rendah.

Berbeda halnya pada kategori I, dan kategori II, pada kategori III kemampuan menganalisis peristiwa dalam kehidupan sehari-hari sangat rendah dimana tidak ada satupun siswa yang dapat menjawab soal. Sedangkan dari hasil wawancara Guru dan siswa diketahui bahwa siswa kelas XI MIA II sangat lemah dalam mengerjakan soal-soal cerita yang berisi perhitungan matematis. Oleh sebab itu mengapa kemampuan analisis siswa masih dikatakan rendah.

Hasil penelitian dapat diketahui, bahwa terdapat banyak faktor yang dapat mempengaruhi belajar siswa terutama pemahaman siswa. Penulis mengklasifikasikan faktor-faktor tersebut ke dalam dua faktor , yaitu faktor internal dan eksternal. Faktor Internal merupaka faktor yang berasal dari dalam diri siswa itu sendiri, sedangkan faktor eksteral merupakan faktor yang berasal dari luar diri siswa atau berasal dari lingkungan. Dalam penelitian ini, penulis membagi faktor internal ke dalam dua aspek, yaitu motivasi dan minat. Sedangkan faktor eksteral meliputi keluarga, sarana dan prasarana dan lingkungan masyarakat. Dari hasil data yang meliputi reduksi data, penyajian data, dan verifikasi atau pengecekkan data diperoleh faktor-faktor yang dominan mempengaruhi belajar siswa

Hasil analisis jawaban wawancara siswa untuk mengetahui motivasi siswa pada kategori I, diketahui bahwa : 1) Siswa selalu mengerjakan pekerjaan rumah yang diberikan oleh guru, baik dikerjakan secara mandiri maupun berkelompok. 2) Sebagian besar siswa belajar ketika akan menghadapi pelajaran fisika, baik ketika mengerjakan PR maupun mempersiapkan diri untuk ulangan. 3) lamanya waktu belajar siswa sangat kurang. Hasil analisis wawancara menunjukkan motivasi siswa dikatakan cukup tinggi. Hasil angket menunjukkan bahwa siswa pada kategori I sebesar 73\%. Sehingga berdasarkan hasil analisis angket, analisis hasil wawancara Siswa dan Analisis wawancara Guru dapat disimpulkan bahwa siswa kategori I memiliki motifasi yang cukup tinggi dalam belajar fisika.

Wawancara siswa untuk mengetahui minat siswa menunjukan hasil analisis pada kategori I diketahui bahwa : 1) siswa menganggap fisika khususnya materi fluida adalah mata pelajaran yang tidak terlalu sulit tetapi kadang bingung tehadap penggunaan rumus, tetapi siswa juga dapat menjawab soal. 2) siswa juga merasa materi fluida statis adalah materi yang mudah untuk dimengerti dari pada materi yang lainnya. 3) siswa antusias dalam mengikuti mengikuti pelajaran fisika. Hasil wawancara diatas menyimpulkan bahwa siswa memiliki minat yang cukup tinggi, dilihat dari antusias siswa yang cukup tinggi dalam mengikuti pembelajaran fisika dan anggapan bahwa fisika khususnya materi fluida statis itu lebih mudah dibandingkan materi yang lain walaupun siswa itu sendiri kesulitan dalam mengerjakan soal. Berdasarkan penuturan Ibu Wanda, selaku Guru mata pelajaran Fisika kelas XI MIA II yang menyatakan bahwa siswa cukup aktif dan antusias dalam mengikuti pembelajaran. Hasil angket menunjukkan bahwa siswa pada Kategori I sebesar $77 \%$ Sehingga berdasarkan hasil analisis angket, analisis hasil wawancara Siswa dan Analisis wawancara Guru dapat disimpulkan bahwa siswa Kategori I memiliki minat yang cukup tinggi dalam belajar fisika.

Berdasarkan hasil analisis wawancara siswa dapat dilihat dari faktor keluarga, menyatakan bahwa orang tua siswa pada kategori I kurang memberikan perhatian yang cukup pada siswa untuk belajar, mengerjakan tugas dan pekerjaan rumah yang diberikan oleh guru. Hasil angket menyatakan bahwa rata-rata pengaruh faktor keluarga terhadap belajar siswa mencapai 63\% dan dapat dikatakan cukup kurang. Sehingga berdasarkan hasil analisis angket dan analisis hasil wawancara siswa dapat disimpulkan bahwa faktor keluarga mempengaruhi belajar siswa.

Petikan wawancara dan angket dilihat dari segi faktor sarana dan prasarana bahwa siswa kategori I memiliki buku pegangan fisika untuk sarana belajar. Siswa kategori I tidak mendapatkan sarana dan prasarana yang mendukung di sekolah. Hal ini ditunjukkan dengan penuturan siswa yang menyatakan bahwa sekolah memiliki laboratorium Fisika tapi tidak difungsikan dengan baik untuk melakukan praktikum. Disamping itu sekolah memiliki perpustakaan yang menyediakan buku-buku pelajaran tapi masi kurang lengkap. Hasil angket pada kategori I menyatakan bahwa pengaruh faktor sarana dan prasarana terhadap belajar siswa mencapai 46\%. Dapat dikatakan rendah, dan faktor sarana dan prasarana merupakan faktor yang paling rendah, dari semua faktorfaktor yang mempengaruhi. Hasil wawancara dengan Ibu Wanda, menyatakan bahwa sangat sulit untuk menghadirkan alat-alat untuk menunjang praktikum siswa baik di Lab. sehingga guru hanya menggunakan demonstrasi di kelas. Sehingga berdasarkan hasil analisis angket, hasil wawancara siswa dan guru dapat disimpulkan bahwa faktor sarana dan prasarana tidak terlalu mendukung dalam pembelajaran siswa. Hal ini ditunjukkan dengan sekolah tidak menyediakan ruang laboratorium yang efesien, alat-alat praktikum serta buku yang kurang 
lengkap yang untuk kegiatan belajar dan praktikukum fisika.

Dari hasil wawancara dan angket yang dilihat dari faktor lingkungan menyatakan bahwa siswa Kategori I rata-rata memiliki lingkungan sekitar rumah yang mendukung untuk belajar di rumah karena kondisi rumah siswa yang sepi dan jauh dari keramaian serta ada internet yang mendukung. Berdasarkan hasil petikan wawancara di atas juga menyatakan bahwa baik kategori I, selalu mengerjakan pekerjaan rumah yang diberikan oleh guru, baik dikerjakan secara mandiri maupun berkelompok. Ini menunjukkan bahwa teman-teman siswa saling mendukung dalam belajar, terbukti dengan semangat untuk mengerjakan tugas secara berkelompok. Siswa kategori I menganggap bahwa Guru mengajar dengan jelas dan sabar. Hal ini dibuktikan dengan Guru tetap mengadakan praktikum atau simulasi sederhana di kelas meskipun di laboratorium disekolah tidak terlalu difungsikan dengan baik serta alat praktikum yang kurang. Sehingga berdasarkan hasil analisis angket, hasil wawancara siswa dan guru kategori I dapat disimpulkan bahwa faktor lingkungan masyarakat mendukung dalam pembelajaran siswa yaitu sekitar $73 \%$.

Sama halnya dengan faktor-faktor yang mempengaruhi hasil belajar pada kategori I, pada kategori II dapat dilihat hasil analisis jawaban wawancara siswa untuk mengetahui motivasi siswa. 1) Siswa selalu berusaha mengerjakan pekerjaan rumah yang diberikan oleh guru, baik dikerjakan secara mandiri maupun berkelompok dan juga bertanya keguru. 2) Sebagian besar siswa juga belajar ketika akan menghadapi pelajaran fisika, baik ketika mengerjakan PR maupun mempersiapkan diri untuk ulangan. 3) lamanya waktu belajar siswa sangat kurang. Hasil analisis wawancara menunjukkan motivasi siswa dikatakan cukup tinggi. Hasil angket menunjukkan bahwa siswa pada kategori II sebesar $78 \%$. Sehingga berdasarkan hasil analisis angket, analisis hasil wawancara Siswa dan Analisis wawancara Guru dapat disimpulkan bahwa siswa kategori II memiliki motifasi yang cukup tinggi dalam belajar fisika.

Dari segi minat siswa pada kategori II diketahui bahwa : 1) siswa menganggap fisika adalah mata pelajaran yang tidak telalu sulit tetapi terkadang bingung dan lupa rumus saat menyalesaikan soal. 2) siswa antusias dalam mengikuti mengikuti pelajaran fisika. Hasil wawancara diatas menyimpulkan bahwa siswa memiliki minat yang cukup tinggi, dilihat dari antusias siswa yang cukup tinggi dalam mengikuti pembelajaran fisika. Hasil angket menunjukkan bahwa siswa pada Kategori II sebesar 83\%. Sehingga berdasarkan hasil analisis angket, analisis hasil wawancara Siswa dan Analisis wawancara Guru dapat disimpulkan bahwa siswa Kategori II memiliki minat yang cukup tinggi dalam belajar fisika dimana faktor minat lebih tingggi dari pada faktor yang lain.

Sama halnya dengan kategori I, kategori II jika dilihat dari faktor keluarga Berdasarkan hasil analisis wawancara siswa bahwa orang tua siswa tidak memberikan perhatian yang cukup pada siswa untuk belajar, mengerjakan tugas dan pekerjaan rumah yang diberikan oleh guru. Hasil angket menyatakan bahwa rata-rata pengaruh faktor keluarga terhadap belajar siswa mencapai $80 \%$ dan dapat dikatakan cukup tinggi.

Dilihat dari hasil pengerjaan angket diperoleh dari segi faktor sarana dan prasarana bahwa siswa kategori II memiliki buku pegangan Fisika untuk sarana belajar. Siswa kurang mendapatkan sarana dan prasarana yang mendukung di sekolah. Hasil angket pada kategori II menyatakan bahwa pengaruh faktor sarana dan prasarana terhadap belajar siswa mencapai 73\%. Dapat dikatakan cukup tinggi.

Dilihat dari faktor lingkungan menyatakan bahwa siswa Kategori II rata-rata memiliki lingkungan sekitar rumah yang mendukung untuk belajar di rumah karena kondisi rumah yang mendukung. Sehingga berdasarkan hasil analisis angket, hasil wawancara siswa dan guru kategori II dapat disimpulkan bahwa faktor lingkungan masyarakat mendukung dalam pembelajaran siswa yaitu sekitar 68\%. Pada kategori II faktor lingkungan yang paling rendah diantara semua faktor-faktor yang lain.

Faktor-faktor yang mempengaruhi hasil belajar siswa, pada kategori III, dimana motifasi belajar siswa sangat rendah yaitu hanya sekitar $68 \%$ jika dibandingkan pada kategori I maupun Kategori II, begitu pula dari faktor minat diperoleh hanya sebesar $73 \%$, dari faktor keluarga diproleh $70 \%$, dari factor ketersedian sarana dan prasaran sebesar $60 \%$, dan dari faktor lingkungan sebesar $60 \%$.

Dapat disimpulkan bahwa baik faktor internal dan eksternal sangat berpengaruh dalam belajar siswa. Dalam faktor Internal, siswa pada kategori III memiliki minat yang tinggi, hal ini ditunjukkan dengan antusiasme siswa yang dalam mempelajari materi fisika walaupun mereka merasa kesulitan dalam mengerjakan soal fisika. Demikian juga dengan motivasi siswa, walau siswa tidak selalu belajar ketika akan menghadapi pelajaran fisika keesokan harinya. Namun demikian siswa selalu mengerjakan tugas yang diberikan oleh guru.

Dalam faktor eksternal, siswa pada kategori III tidak mendapatkan perhatian yang cukup dari orang tua dalam hal pendidikan, siswa pada tidak 
mendapatkan sarana dan prasarana yang memadai dalam belajar. Hal ini ditunjukkan dengan tidak berfungsi dengan efesienya ruang laboratorium yang memadai untuk mengadakan praktikum. Meski demikian sekolah tetap menyediaka perpustakaan sekolah yang membantu siswa dalam mengerjakan tugas, dan sebagian besar siswa memiliki buku cetak sebagai pegangan mereka dalam belajar di rumah dan mempersiapkan materi sebelum mengikuti pembelajaran fisika di sekolah. Siswa juga memiliki lingkungan sekitar yang mendukung untuk belajar, ditunjukkan dengan kondisi teman sebaya yang mendukung dalam belajar terutama saat mengerjakan tugas, dan Guru yang memberikan perhatian penuh dalam mengajarkan materi fisika kepada muridnya.

Baik faktor internal dan eksternal yang mempengaruhi belajar siswa digolongkan tinggi. Meski demikian dapat diketahui bahwa sarana dan prasarana siswa kurang menunjang dalam belajar. Sekolah memang memiliki ruang laboratorium, tapi tidak difungsikan dengan efisien dikarenakan alat-alat laboratorium masi belum tertata dengan baikdan masih belum legkap. Sehingga baik guru maupun siswa kesulitan dalam melakukan praktikum fisika. Padahal dalam kenyataannya fisika bukan hanya sekedar menghafal teori, namun untuk memahami konsepnya dan penerapannya dilingkungan sekitar dibutuhkan contoh yang nyata yang dapat dilakukan dengan praktikum.

Seperti halnya yang dikemukakan oleh Van Denberg dan Liem [11], mempelajari fisika tidak cukup hanya dengan buku-buku sebagai acuan untuk memperoleh teori melainkan juga perlu didukung dengan perlengkapan untuk demonstrasi, eksperimen, atau praktek.

\section{KESIMPULAN}

\section{A. Kesimpulan}

Berdasarkan

hasil penelitian, dapat disimpulkan bahwa banyaknya siswa kelas XI MIA II yang masuk Kategori I, dimana siswa mampu memahami konsep fisika juga memahami penerapannya di lingkungan sekitar yaitu sebanyak $8 \%$, dan masih dikatakan rendah. Dari hasil angket dan wawancara yang diberikan kepada siswa, diketahui bahwa faktorfaktor yang mempengaruhi belajar siswa yaitu faktor internal (diri sendiri) yaitu minat sebesar $77 \%$ dan motivasi sebesar $73 \%$ dan dari faktor eksternal yaitu keluarga sebesar $63 \%$, sarana dan prasarana sebesar $46 \%$, dan lingkungan masyarakat sebesar $73 \%$. Dan juga siswa pada kategori I memiliki kemampuan menganalisis yang cukup tinggi. Hal ini dibuktikan dengan dilihat dari materi Tekanan Hidrostatis yang diperoleh siswa sebesar $80 \%$, materi hukum pascal sebesar $70 \%$, dan untuk materi Hukum Archimedes sebesar $50 \%$.

Pada kategori II, dimana siswa dapat memahami konsep fisika tatapi kurang terampil dalam penerapannya dilingkungan sekitar yaitu sebanyak $83 \%$, dari faktor internal yaitu motifasi sebesar $78 \%$ dan minat sebesar $83 \%$ dan dari faktor eksternal yaitu keluarga sebesar $80 \%$, sarana dan prasarana sebesar $73 \%$, dan lingkungan masyarakat sebesar $68 \%$. Dan juga siswa pada kategori ini memiliki kemampuan menganalisis peristiwa dalam kehidupan seharihari yang cukup rendah, untuk materi Tekanan Hidrostatis yang diperoleh siswa sebesar 36\%, materi hukum pascal sebesar $61 \%$, dan untuk materi Hukum Archimedes sebesar 21\%.

Pada kategori III, dimana siswa berada pada tingkat yang tidak terlalu mamahami konsep tetapi terampil dalam penerapannya dilingkungan sekitar diperoleh sebanyak $29 \%$. Dari faktor yang mempengaruhi belajar mereka dari faktor internal yaitu motifasi sebesar $68 \%$ dan minat sebesar $73 \%$ dan dari faktor eksternal yaitu keluarga sebesar $70 \%$, sarana dan prasarana sebesar $60 \%$, dan lingkungan masyarakat sebesar $60 \%$. Dan juga siswa pada kategori ini memiliki kemampuan menganalisis peristiwa dalam kehidupan sehari-hari yang sangat rendah dimana tidak ada satupun siswa yang dapat menjawab soal menganalisis.

\section{B. Saran}

Berdasarkan kesimpulan, maka penulis mengajukan beberapa saran agar menjadi masukan yang berguna, diantaranya yaitu:

1. Dalam memberikan pembelajaran fisika, disamping mengajarkan konsep fisika, guru juga harus menunjukkan penerapan fisika di lingkungan sekitar. Sehingga siswa dapat memahami contoh nyata yang dapat diamati dalam kehidupan sehari-hari.

2. Sekolah harus memperhatikan sarana dan prasarana yang mendukung dalam pembelajaran. Dalam hal ini sekolah diharapkan dapat menyediakan laboratorium fisika sebagai tempat siswa dan guru dapat melakukan praktikum fisika.

3. Guru juga harus membekali siswa dengan keterampilan menganalisis, dengan rutin memberikan contoh-contoh soal yang berkaitan degan kehidupan sehari-hari sehingga kemampuan menganalisis siswa dapat meningkat. 


\section{DAFTAR PUSTAKA}

[1] Hadiwiyanti, Irma. (2015). Analisis Pemahaan Konsep Fisika Siwa SMP dan Penerapannya Di Lingkungan Sekitar. Skripsi. Semarang: UNS

[2] Depdiknas. (2002). Kompetensi Dasar Mata Pelajaran Fisika SMA \& MA. Jakarta: Balitbang.

[3] Ain, T. N. (2013). Pemanfaatan Visualisasi Video Percobaan Gravity Current Untuk Meningkatkan Pemahaman Konsep Fisika Pada Materi Tekanan Hidrostatis .Jurnal Inovasi Pendidikan Fisika, Vol. 2 (02).

[4] Anderson, Lorin W. \& Krathwohl, D. R. (2001). A Taxonomy for Learning, Teaching and Assesing: a Revision of Bloom's Taxonomy. New York. LongmanPublishing.http://www, kurwongbss.qld.edu.au/ thinking/Bloom/blooms.htm.

[5] Saleh, Salmiza. (2011). The Level of B.Sc.Ed Students' Conceptual Understanding of Newtonian Physics. International Journal of Academic Research in Business and Social Sciences, Vol. 1 (03).
[6] Masril. (2008). Penerapan Model Pembelajaran Vee Map Melalui Belajar Kooperatif di SMA Negeri 2 Padang. Artikel. Padang: Jurusan Fisika FMIPA UNP.

[7] Sugiyono, (2008). Statistik untuk Penelitian. Bandung: CV. Alfabeta.

[8] Arikunto, S.,\& Jabar, C. S. A. (2004). Evaluasi Program Pendidikan. Jakarta: Bumi Aksara.

[9] OECD, (2007). PISA 2006 Science Competencies for Tomorrow's World Volume I.[Online]. Tersedia: http://www. pisa.oecd.org/dataoecd/30/17/39703267.pd f (22 Sebtember 2016).

[10] Wildaiman. 2005. Pro-Kontra UAN, Sekolah, Bimbel dan Mutu Pendidikan. Media Cetak : Pikiran Rakyat 31 Januari 2005.

[11] Awitaningsih, E, N., Sutarto, Supriadi, B. 2012. Studi Pemanfaatan Peralatan Laboratorium Fisika Dalam Mendukung Pelaksanaan Pembelajaran Fisika Kelas $X$ dan XI di SMA Negeri Kabopate Banyuwangi Wilayah Selatan Barat. Jurnal Pembelajaran Fisika, Vol. 1 (02). 